\title{
FINDING INVISIBLE ARIANS: AN ARCHAEOLOGICAL PERSPECTIVE ON CHURCHES, BAPTISM AND RELIGIOUS COMPETITION IN $6^{\text {th }}$ CENTURY SPAIN
}

\section{ALEXANDRA CHAVARRÎA ARNAU}

\author{
UDC: 2-7(365)"05" \\ 902.2 \\ Original scientific paper \\ Manuscript received: 19. 03. 2017. \\ Revised manuscript accepted: 31. 03. 2017. \\ DOI: 10.1484/J.HAM.5.113755
}

\author{
A. Chavarría Arnau \\ Dipartimento dei Beni Culturali \\ Università degli Studi di Padova \\ Piazza Capitaniato 7, 35139 Padova, Italia \\ Chavarria@ unipd.it
}

\begin{abstract}
The sixth century witnessed the installation of the Visigoths in the Peninsula following their defeat by the Franks in 507; Ostrogothic domination, first by Theodoric (509-527) and later by Theudis (531-548); and the presence of imperial troops in the South-East. The end of the century saw the conversion of arian goths to catholicism in the Third Council of Toledo (589). As written sources were extremely biased and influenced by the eventual outcome, the archaeology of churches is an essential tool for reconstructing this period of history in the iberian peninsula and particularly the religious and political competition between Arians and followers of the nicene creed.
\end{abstract}

Keywords: Arianism, churches, baptism, bishops, Spain, late antiquity

\section{INTRODUCTION}

The subject of Arianism as a religious doctrine which set apart a number of barbarian peoples (Vandals, Burgundians, Goths and Lombards) when they settled the Western Mediterranean has received little attention from scholars of the period, in accordance with the trend prevailing in recent decades of emphasising points of contact and continuity between barbarians and Romans, rather than areas of tension and breakdown. Since in late antiquity religion was an element of pivotal importance, not only within ideological and cultural life but also, and crucially, to political relationships between the different kingdoms and between them and the Eastern Empire, the religious creed of the ruling elites, and the conflicts that these could produce between them and the local population, is a subject that cannot be ignored. Not only do contemporary sources speak of its importance, but also we believe this is essential to explaining the extraordinary development of ecclesiastical architecture in Hispania during the course of the sixth century. This period has been studied much less than the preceding centuries (when the Christianisation of cities and their local territory took place) or the century following 589, when the Visigoths converted to Catholicism. The sixth century witnessed the installation of the Visigoths in the Peninsula following their defeat by the Franks in 507; Ostrogothic domination, first by Theodoric (509-527) and later by Theudis (531-548); and the presence of imperial troops in the South-East, aided by an internal conflict between different Visigothic factions and between these factions and the Hispano-Roman population, tensions which were to be more or less resolved by the Third Council of Toledo (589). As written sources (especially Isidore of Seville, Juan de Biclaro and hagiographic writings) were extremely biased and influenced by the eventual outcome (victory of the Visigoths over the imperial troops and consolidation of the Visigothic kingdom of Toledo), and Arian texts were subjected to massive destruction after the conversion, the archaeology of churches is an essential tool for reconstructing this period of history.

\section{VISIGOTHS AND ARIANISM}

The Visigoths became Arians when they entered imperial territory in the year $376^{1}$. At that time, the emperor Valens was an Arian, and so adopting Arianism has been interpreted as a method used by the Goths to "Romanise" or become assimilated into the Roman people, some of whom were Arian ${ }^{2}$. The fact that the Goths and other barbarian peoples were Arians can thus be interpreted as purely due to circumstances. Under Theodosius and after the council of Constantinople in 381, the creed laid down by the Council of Nicaea (325), which defended the consubstantiality of the Holy Spirit, Father and Son, became the official doctrine and Arianism became, along with other variants of Christianity, a heresy that was to a greater or lesser extent persecuted by the emperors.

However, the Goths continued to profess homoiousian Arianism (which affirmed that the son was similar (homoiousios) to the Father ${ }^{3}$ ) probably converting this into an element of ethnic identity that allowed them to set

${ }^{1}$ See P. HEATHER, J. MATTHEWS The Goths in the Fourth Century, Liverpool, 1991, pp. 137-139 and a recent synthesis the texts collected in G. BERNDT and R. STEINACHER, Arianism: Roman Heresy and Barbarian Creed, Farnham, 2014. To give a simple summary, during this period Catholics and Arians differed in their conceptions of the Trinity and especially of the nature of the Father and Christ (logos), which had been created first, and their distinct substance.

${ }^{2}$ Cfr. E. A. THOMPSON, The Visigoths at the time of Urfila, 1966, pp. 115-117; K. SCHÄFERDIEK, Die Anfänge des Christentum bei den Goten un der so genante gotische Arianismus, "Zeitschrift für Kirchengeschichte", 112, 2001, pp. 295-310; H.C. BRENNECKE, Deconstruction of the so called germanic Arianism, in G. BERNDT and R. STEINACHER (eds.), Arianism: Roman Heresy and Barbarian Creed, Farnham, 2014, pp. 117-130.

${ }^{3}$ M. MESLIN, Les Ariens d'Occident (335-430), París, 1967. 
themselves apart from the Roman population, one of the many "distinction strategies" that barbarians adopted at this particular time in history in order to create their own separate identity 4 . In this they were not alone, and it appears that anti-Arian legislation did not apply in the military sphere, where many soldiers were of barbarian origin ${ }^{5}$.

We have little information about the Arianism of the Visigoths before and after their settlement in Hispania: in the adulatory description of Theodoric II and his court in Toulouse, Sidonius Apollinaris relates that the king began his day very early by taking part in an Arian ecclesiastical service $^{6}$. Around 465 , this same king appears to have commenced an evangelising expedition to Galicia, headed by a certain Ajax, in order to convert the Suebi to Arianism (Hydatius, Chronica, 228 [232]). Olympiodorus mentions the Arian bishop Sigesaurus, whom he accompanied to the court of Ataulf when he was assassinated in Barcino ${ }^{7}$. Visigoth monarchs like Euric or Alaric II did not hesitate to send into exile bishops who, as ringleaders of the Roman population, fomented movements against them (such as, for example, Sidonius Apollinaris), which led to the abandonment of many churches throughout the territory 8 .

In general, scholars who have analysed these events have emphasised the "political" character of these actions and proposed that these acts by Visigoth kings had little religious "content". This is idea ought to be nuanced, given that we are dealing with a period when religion and politics were intimately linked since, it must be remembered, it was kings who decided and imposed religion upon their subjects. On the other hand, it is also true that this choice often depended on the political strategies of the sovereigns, and was also based, at this time, on the extent to which they wished to associate or ally with the Eastern Roman Empire.

During the period of Ostrogothic control over the Peninsula, two epistles written by the bishop of Toledo, Montano (c. 523-531), allude to ecclesiastical problems in the northern Meseta. Montano, addressing the clergy of Palencia and a certain Toribio, firstly denounced the fact that the clergy were consecrating the chrism (for being used in baptism); and, secondly, that bishops of other provinces were presiding over ceremonies of consecration of the basilicas in this area $^{9}$. In both cases, these procedures were forbidden by the Catholic church and so needed to be corrected. Montano also praised his interlocutor Toribio for having guided a certain number of the powerful on to the true pathway in religious matters (ad salubrem regulam et normam regularis disciplinae). In general, the content of this document has been tied to the Priscillian controversy and the survival of heretical currents in this region, to which Montano also makes allusion. However, if we take into account the date (more than 150 years after Priscillian had been executed) ${ }^{10}$, the historical period in which it was written (Ostrogothic dominance), the area (northern Meseta, where there were probably areas occupied by Gothic peoples" ${ }^{11}$ and the type of accusation the bishop of Toledo makes, Montano could well be referring to problems of Arian communities there ${ }^{12}$.

The existence of bishops claiming jurisdiction outside their diocese calls to mind the second canon of the Council of Constantinople in 381 relating to the organising of churches of barbarian peoples, which states that Arian bishops apparently had more extensive powers than Catholic ones, or at least were not limited to their own diocese. Again, the clergy appeared to have broader powers than Catholic ones. For example, in an inscription from the south of Gaul, a priest named Othia (probably a Visigoth), dedicated a basilica to Saints Felix, Ines and Eulalia, dating the dedication to his own priesthood. This was unthinkable for the Catholic hierarchy, where the dedication of a church was a prerogative set aside exclusively for a bishop ${ }^{13}$. A number of the canons from councils following the Third Council of Toledo, which dealt with questions of the exclusivity of the bishop in consecrating the chrism, may be a reflection of corrections made to practices performed by Arian clergy who had converted to Catholicism but were reluctant to abandon these practices.

Sixth century councils underline the preoccupation of Catholic authorities with the advances made by Arianism and these allow us to see how this "heresy" had expanded more than many investigators acknowledge. At the council of Ilerda (Lérida) in north-eastern Hispania, held in 546, those who submitted voluntarily to a reiteration of baptism were condemned, since this was a practice that was not allowed under Catholic legislation (canon 9). This same Council condemned fathers who baptised their offspring into Arianism (canon 13) and those taking part in ceremonies and banquets alongside those who had been baptised again (canon 14). This council thus shows that there were

\footnotetext{
${ }^{4}$ W. POHL, Strategies of Distinction: The construction of Ethnic communities, 300-80o, Leiden, 1998.

${ }^{5}$ R. W. MATHISEN, Sigisvult the Patrician, Maximinus the Arian, and Political Stratagems in the Western Roman Empire ca. 425-440, "Early Medieval Europe", 8.2, 1999, pp. 173-196.

${ }^{6}$ Sidonius Apollinaris, Epistulae, I, 2, Carmina 7.

7 Olympiodorus, frag. 26, J. ARCE, Bárbaros y romanos en Hispania. 400-507 A.D., Madrid, 2007, p. 84.

${ }^{8}$ R. W. MATHISEN 1997, Barbarian Bishops and the. Churches "in barbaricis gentibus" during Late Antiquity, "Speculum", 72, 1997, pp. 682-683.

${ }^{9}$ ad consacrationem basilicarum alienae sortis a uobis episcopi invitentur..., I, 1. 202-203 (Deeds of the Second Council of Toledo). For the canons of the individual councils cited in this volume the edition by G. MARTÍNEZ DIEZ, F. RODRÍGUEZ, La Colección Canónica Hispánica, Madrid has been used.

${ }^{10}$ H. CHADWICK, Prisciliano de Avila, Madrid, 1978 and V. BURRUS, The Making of a Heretic. Gender, Authority, and the Priscillianist Controversy, Berkeley, Los Angeles, London, 1995.

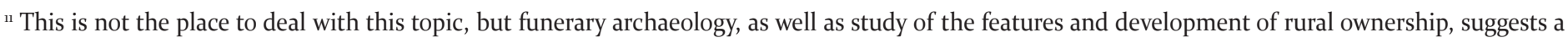
wide settlement of non-native populations in this region, probably after mid fifth century, cfr. A. CHAVARRÍA ARNAU, ¿Castillos en el aire? Paradigmas interpretativos "de moda" en la arqueología medieval española, in De Mahoma a Carlomagno. Los primeros tiempos (ss. VII-IX), XXXIX Semana de estudios medievales de Estella (17-20 julio 2012), 2013, pp. 131-166.

${ }^{12}$ As proposed by M. KOCH, Arianism and Ethnic Identity in 6 th century Visigothic Spain, in G. BERNDT, R. STEINACHER (eds.), Arianism: Roman Heresy and Barbarian Creed, Farnham, 2014, pp. 266-267. On the unreliability of mentions of priscillianism in council deeds of the Visigoth era, cfr. J. WOOD, Elites and Baptism: Religious 'Strategies of Distinction' in Visigothic Spain, "Studies in Church History”, 42, Cambridge, 2006, pp. 8-9.

${ }_{13} \mathrm{CIL}_{12}, 04311=\mathrm{ILGN}+00557=\mathrm{ILCV} 01807$ (add) $=\mathrm{ILCV}+02021=\mathrm{ILCV}+01167=\mathrm{AE}$ 2010, $00918=\mathrm{EDCS}-09301476$.
} 
Arians who had passed to the Catholic faith and also that the opposite was true, and that there was close contact between both groups. It is also obvious that, if fathers baptised their offspring into the faith of Visigoth elites, this was because they felt that they could gain some advantage from it.

During the period of Ostrogothic dominance, there is no information concerning anti-Catholic reactions, which fits with the policy of cooperation with Roman communities put into practice by Theudis, in imitation of the actions of Theodoric in Italy, although it should be noted that there are many churches set up by the Ostrogothic king in the capital and in other important cities of his realm ${ }^{14}$. After his assassination, his successor Agila adopted a more intransigent stance towards the Catholic population, whom he treated harshly. In 550 , he even profaned the tomb of Saint Acisclus in Corduba (as recorded by Isidore: "in contemptu catholicae religionis", Historia Gothorum, 45), an offence which brought about the resounding defeat of the Visigoth king and the death of his son. It is likely that he even prohibited Catholic synods from being held. We know nothing of the religious policies of Athanagild, although, taking into account his opposition to Agila and the fact that he sought the cooperation of the Catholics of the empire, he must have been more moderate.

The time of greatest tension, and best documented by written sources, appears to have occurred at the time of Liuvigild, when religious matters became an excuse for conflict between the monarch and his son Hermenegild, as recorded by later texts. In various passages, Gregory of Tours describes the persecutions by Visigoths of Catholics, who were deprived of their property, beaten, made prisoner, etc. (Historiae IV, 8). Hispanic sources concur, and relate that Liuvigild also sought to counteract Catholic authorities by encouraging conversion to Arianism by a number of bishops like Vicente from Caesaraugusta (Zaragoza), banishing any prelates who opposed his policies ${ }^{15}$ and confiscating reditos et priuilegia of Catholic churches. In Emerita (Mérida), he seized a number of basilicas with all their privilege ${ }^{16}$ so they could be used by the Arian community, headed by Bishop Sunna (Vitas Sanctorum Patrum Emeretensium, V, 5,4).

In the year 580 - in the midst of the conflict with his son Hermenegild - the king convened an Arian council in Toledo, where a number of theological and liturgical changes were made to encourage conversions to Arianism. In particular, Liuvigild ordered the suppression of the demand to reiterate baptism, which was a delicate issue as the Catholic Church Fathers roundly prohibited the repetition of this ritual. Conversion thus became reduced to a laying on of hands, receiving communion and reciting the Trinitarian doxology according to the formula 'Gloria Patri per Filium in Spirito Sancto', thus recognising a parity between Father and Son (but not the Holy Spirit) (Juan de Biclaro, Chronica a. 580, 200-208).

\section{ARIAN CHURCHES IN HISPANIA}

Clearly Arians needed places for their faithful to meet, be baptised, and pray. Documentary sources suggest various possibilities: in a number of cases they took over Catholic churches and adapted them to Arian use, as we have seen happened in Mérida, although we do not know which churches are referred to, and it appears that the cathedral stayed in Catholic hands. In Toledo, an inscription ${ }^{17}$, found in the sixteenth century not far from the current cathedral, appears to celebrate the reconversion by King Reccared to Catholic use of a church devoted to Santa Maria (most probably the cathedral). This implies that in the capital of the kingdom, Arians had previously converted to their use the ecclesia episcopalis (which dated from at least the end of the fourth century), and it was then restored to Catholic use. At the Council of Zaragoza in 592, immediately after this reconversion, a discussion was held regarding what was to be done to integrate the former Arian clergy, relics and basilicas. A mass was possibly held to reconvert the church of Santa Engracia in the city, which had been converted to Arianism by the apostate bishop Vicente. It is therefore not possible to identify any standard procedure, and probably the importance of churches which were or were not converted by Arians depended on the relative strength of the local Catholic or Arian élites.

Another possibility is that Arians built their own churches. The sole known example in Hispania of a church possibly constructed by the order of an Arian (King Liuvigild) is that at Cerro de la Oliva (Guadalajara), assuming that this is the settlement identified as Recopolis and also that the church was part of the original design of the urban centre. This church has a cruciform plan, partially built in opus quadratum with ashlar stone from a nearby quarry, a possible baptistery and elements of richly decorated liturgical enclosures (fig. 1) ${ }^{18}$.

We have no knowledge of any other church which was definitely built for Arian worship. Most investigators agree that there were no major differences between Catholic and Arian churches, because the liturgical distinctions between the two confessions were mostly limited to the system of baptism $^{19}$. Additionally, when these buildings were converted to the orthodoxy (Third Council of Toledo, canon 9)

\footnotetext{
${ }_{14}$ D. MAUSKOPF DELIYANNIS, Ravenna in Late Antiquity, Cambridge, 2010, pp. 142-144.

${ }^{15}$ See M. VALLEJO GIRVÉS, Banishings of Catholics and Arians under Liuvigild and Reccared, "Hispania Sacra”, 2003 , pp. 55, 35-47.

${ }^{16}$ Isidore, Historia Gothorum 50, 1-5. We do not know what these privileges were, since the granting (or denying) of privileges by the authorities was common practice during late antiquity and may refer to very distinct issues. In connection with owners, privileges above all concerned fiscal immunities or rights of prescriptions (R. ARCURI, I beni della Chiesa nel VI. Sec. d.C. tra economia, diritto e religione, "Atti dell'Academia Pontaniana”, 61, 2012, pp. 123-137).

${ }_{17}$ ICERV n. 302, interpreted by I. VELÁZQUEZ 2014, Epigrafía en la Hispania de época visigoda: nuevas perspectivas, revisiones críticas y estudios, en C. Codoñer, P.F. ALBERTO (ed.), Wisigothica after M. Díaz y Díaz, Florencia, 2014, pp. 307-328 as: In the name of the Lord the church of Santa Maria has been consecrated under the Catholic rite, on Sunday the ides of April and in the first year of the reign of our lord Reccared, in the era 625, which corresponds to Sunday $13^{\text {th }}$ April 587 .

${ }^{18}$ Cfr. L. OLMO, Recópolis y la ciudad en época visigoda, Madrid, 2008.

19 D.M. GWYNN, Archaeology and the 'Arian controversy' in the fourth century, in D.M. GWYNN and S. BANGERT (eds.), Religious Diversity in Late Antiquity, Leiden-Boston, 2010, pp. 229-263; B. WARD PERKINS, Where is the archaeology and iconography of Germanic Arianism?, in D.M. GWYNN, S. BANGERT (eds.) Religious Diversity in Late Antiquity, Leiden-Boston, 2010, p. 267; R. BOCKMANN, The Non-Archaeology of Arianism, in G. M. BERNDT and R. STEINACHER (eds.), Arianism: Roman Heresy and Barbarian Creed, Farnham-Burlington, 2016, pp. $201-218$.
} 

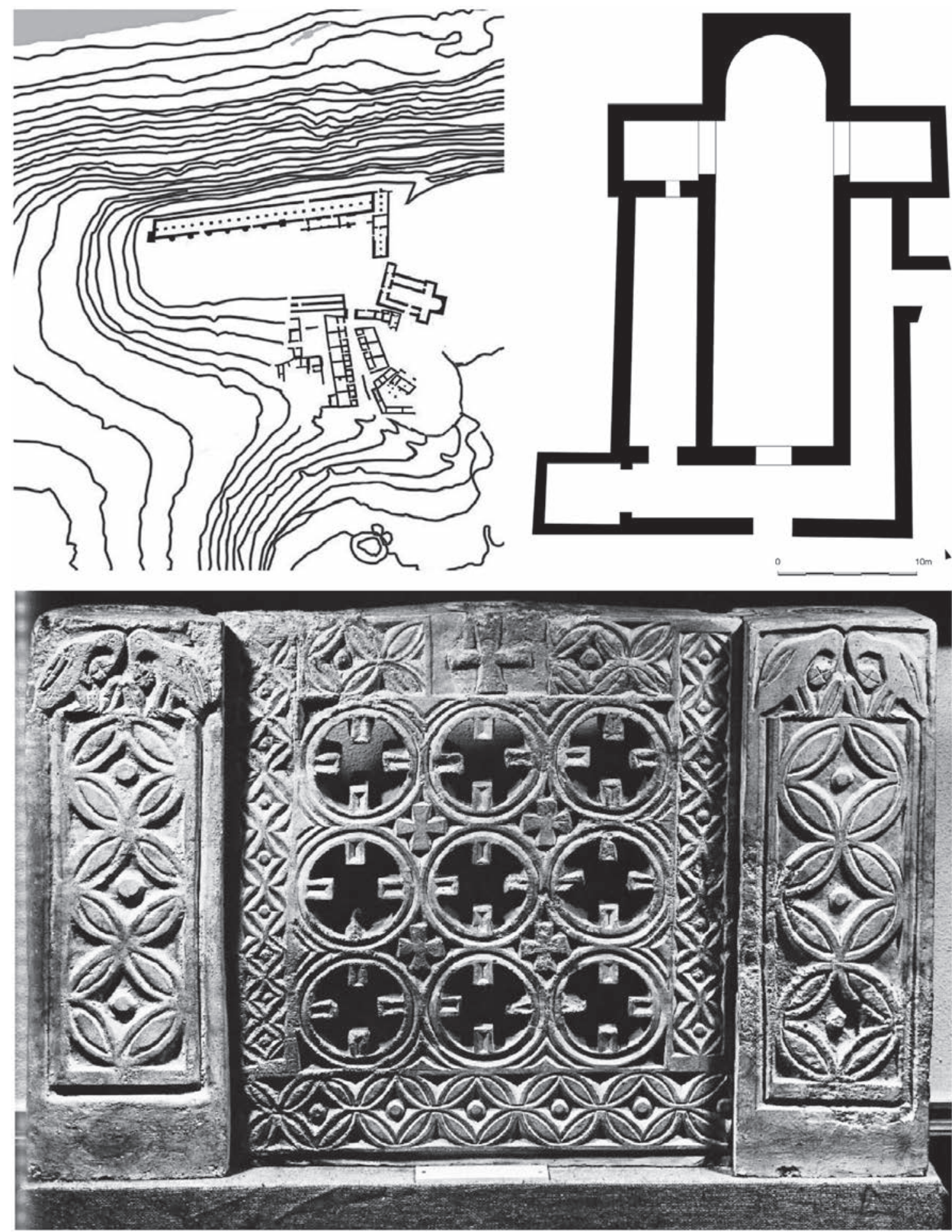

Fig. 1: Plan of the excavated area of Recopolis (Zorita de los Canes, Guadalajara), the church and part of its liturgical furnishing.

after Catholic conversion, they sometimes changed their dedication, and thus without any textual evidence they are almost impossible to identify. In Italy, we know of the magnificent Arian churches built by the Ostrogothic king in Ravenna (the Arian cathedral and the palace church of Sant'Apollinare Nuovo - originally dedicated to Our Lord Jesus Christ- among others), but written sources refer to other Arian buildings in Rome, Milan, Aquileia, Verona and
Pavia, in some cases built by the Lombard monarchs, who alternated between the practises of Arianism and Catholicism up until the end of the seventh century ${ }^{20}$.

Once they had been converted to Catholicism, these buildings were generally rededicated to anti-Arian saints like San Eusebio (bishop of Vercelli), Saint Zeno (bishop of Verona) or especially Saint Martin, a saint who spent most of his youth in the North of Italy combating Arianism, which

\footnotetext{
${ }^{20}$ M. CECCHELLI, G. BERTELLI, Edifici di culto ariano in Italia, in Actes du XIe congrès international d'Archéologie chrétienne (Lyon, Vienne, Grenoble, Genève, Aoste, 21-28 septembre 1986), París, 1989, pp. 233-247) continue to rely on the textual documentation, following J. ZEILLER, Étude sur l>Arianisme en Italie à l'époque ostrogothique et à l'époque Lombarde, «Mélanges d'archéologie et d'histoire», 25, 1905, pp. 127-146. A recent synthesis of archaeological evidence for the Lombard phase in A. CHAVARRÍA ARNAU, Le chiese dei Longobardi, in I Longobardi. Un popolo che cambiò l'Italia, Exhibition catalogue (Pavia, expected 2017)
} 
was widespread and the cause of fierce conflicts between Catholic religious authorities and political elites at the time of Martin and Ambrose. The palace church built by Theodoric at Ravenna was rededicated to Saint Martin after its conversion, and it is no coincidence that many churches built in areas of Lombard settlement in Italy were dedicated to this saint ${ }^{21}$. The anti-Arian character of Saint Martin also explains the dedication of the church built by the Suebian king Chararic, when he promised to convert to Catholicism at the start of the sixth century. This is perhaps the church near which Martin of Braccara, who was mainly responsible for the conversion of the Suebi, constructed a monastery in the middle of the century (Gregorio de Tours, De miraculis sancti Martini 11). It is therefore possible to hypothesise that many sixth century Hispanic churches with this name can be understood from this perspective, although of course case by case analysis is essential.

It is difficult to establish with certainty how many cities in Hispania had Arian episcopal seats in the middle of the sixth century. At the Third Council of Toledo there were eight Arian bishops who converted to Catholicism: Ugnus de Barcino, Ubiligisclus and Murila de Valentia, Sunila de Viseo, Gardingus de Tui, Bechila de Lucus, Argiovitus de Portus Cale (Porto) and Fruisclus de Dertosa. But the acta do not mention the bishops of three of the most important Visigothic urban seats of the time: Sunna of Narbo, Ataloco of Emerita and Uldila of Toletum. Thus it is likely that cities with Arian bishops were much more numerous than the acta record, and that not all the bishops abjured at the Council of 589. In fact, sources refer to important reactions after the conversion of Reccared, headed specifically by Arian bishops from cities dominated by Gothic élites. Nor do we know whether in every city where there was an Arian bishop there was also a corresponding Catholic one. This is a problem which we currently cannot solve, due to our lack of knowledge of how these seats functioned when there were Arian bishops there. In Emerita, the exile of Masona, described in detail in the Vitas Sanctorum Patrum Emeretensium, led to his replacement by another Catholic bishop, which indicates that the presence of an orthodox bishop was indispensable in places where most of the population continued to be Catholic. That means, in my view, that in many cities two churches must have existed, with two baptisteries, such as those still standing today in Ravenna, or those which have recently been identified in the city of Mantua, one of which dates from Lombard times ${ }^{22}$.

\section{ARCHAEOLOGICAL EVIDENCE FOR SPANISH CHURCHES DURING THE SIXTH CENTURY}

Archaeological documentation is thus essential testimony for our understanding of the magnitude of the phenomenon. Rather than directly seeking the remains of Arian churches (which, as discussed, are difficult to recognise), it may be more productive to initiate an analysis of archaeological documentation relating to churches of the sixth century in conjunction with the textual sources, in order to demonstrate that there were a large number of churches built in areas where there was probably religious competition.

The main problem for an archaeologist when dealing with the question of late antique churches in Hispania, not only those from the sixth century, but also earlier and, especially, later ones, is their chronology. Most of these buildings have not been well dated, either because during excavations no materials were found which would enable the initial chronology of the structures to be determined, or, in cases of dispersed, generally sculptural, material, the chronologies are too broad or even actually mistaken. In the case of excavated buildings, it is usual to establish a terminus ante quem relative to epigraphy or to funerary objects from associated tombs, or sometimes the materials that mark its abandonment. In terms of architectural decorations (capitals, columns and friezes) or liturgical objects (screens, altars, liturgical bronzes), there is no systematic study or complete catalogue of Hispanic material and they are often dated to "Visigothic times" without defining any century. All too often, where there are no precise chronological indicators, buildings and materials are dated to a questionable "end of sixth century-seventh century" date, i.e. post 589, clearly to support their interpretation as a consequence of the triumph of Catholicism over Arianism ${ }^{23}$. In my view, this assumption is without foundation and, as we shall see, in those few instances when the data are certain, chronologies tend to sit precisely in the period prior to the Third Council of Toledo. This is obviously not to say that all late antique churches date to the sixth century, nor that they are Arian. The building of the ecclesiastical network took place from the fourth century (and, according to the Council of Elvira, churches already existed at the start of that century) up until well beyond 711 . Throughout history, however, the construction of churches could fulfil distinct functions and meanings, and so analysing these buildings is a fundamental tool for the historical reconstruction of each period.

It is very likely that the first urban churches in Hispania ${ }^{24}$ were built in the early years of the fourth century, as it appears from the Council of Elvira that numerous Hispanic bishops attended in the ecclesia of the city. However, the existing archaeological evidence cannot be dated prior to the mid-sixth century, and is notably scarce, consisting only of the first baptistery in the bishop's church of Barcino (Barcelona) and structures that can also be dated to the sixth century around Ergara (Terrassa). The Christian community in Emerita was among the first in Hispania, and it is more than likely that in the fourth century there was already a church there where the community gathered. This is confirmed by a text mentioning the cathedral as the scene of conflict in 380 between the bishop of the city, Hydatius, and his pro-Priscillian challengers ${ }^{25}$. This building, for which

\footnotetext{
${ }^{21}$ S. LUSUARDI SIENA, E. SPALLA, I siti archeologici del nord Italia legati al titulus Martini: alcune considerazioni, “Temporis Signa”, VI, 2011, pp. 1-58.

${ }^{22}$ A. MANICARDI, Mantova: topografia e potenziale archeologico della civitas vetus dalla tarda antichità all'alto medioevo, Mantova, 2015.

${ }^{23}$ For example in H. SCHLUNK, T. HAUSCHILD, Hispania Antiqua. Die Denkmäler der frühchristliche und Westgotische Zeit, Mainz, 1978, followed by most Spanish researchers up to today.

${ }^{24}$ A synthesis of the earliest evidence of Hispanic Christianity in A. CHAVARRÍA ARNAU, Constructing Christian Landscapes in the Iberian Peninsula: The Archaeological Evidence (4 $4^{\text {th }} 6^{\text {th }}$ centuries), in D. K. PETTEGREW, W. CARAHER, T. DAVIS (eds.), The Oxford Handbook of Early Christian Archaeology, Oxford i.p. (expected 2017).

${ }^{25}$ H. CHADWICK, op. cit. (n. 10) (on having sexual relations with his wife or having had a son in secret.), cfr. also J. ARCE, Augusta Emerita en el siglo V, in J. ARCE (ed.), Mérida Tardorromana (300-580 d.C.), Mérida, 2002, p. 189.
} 


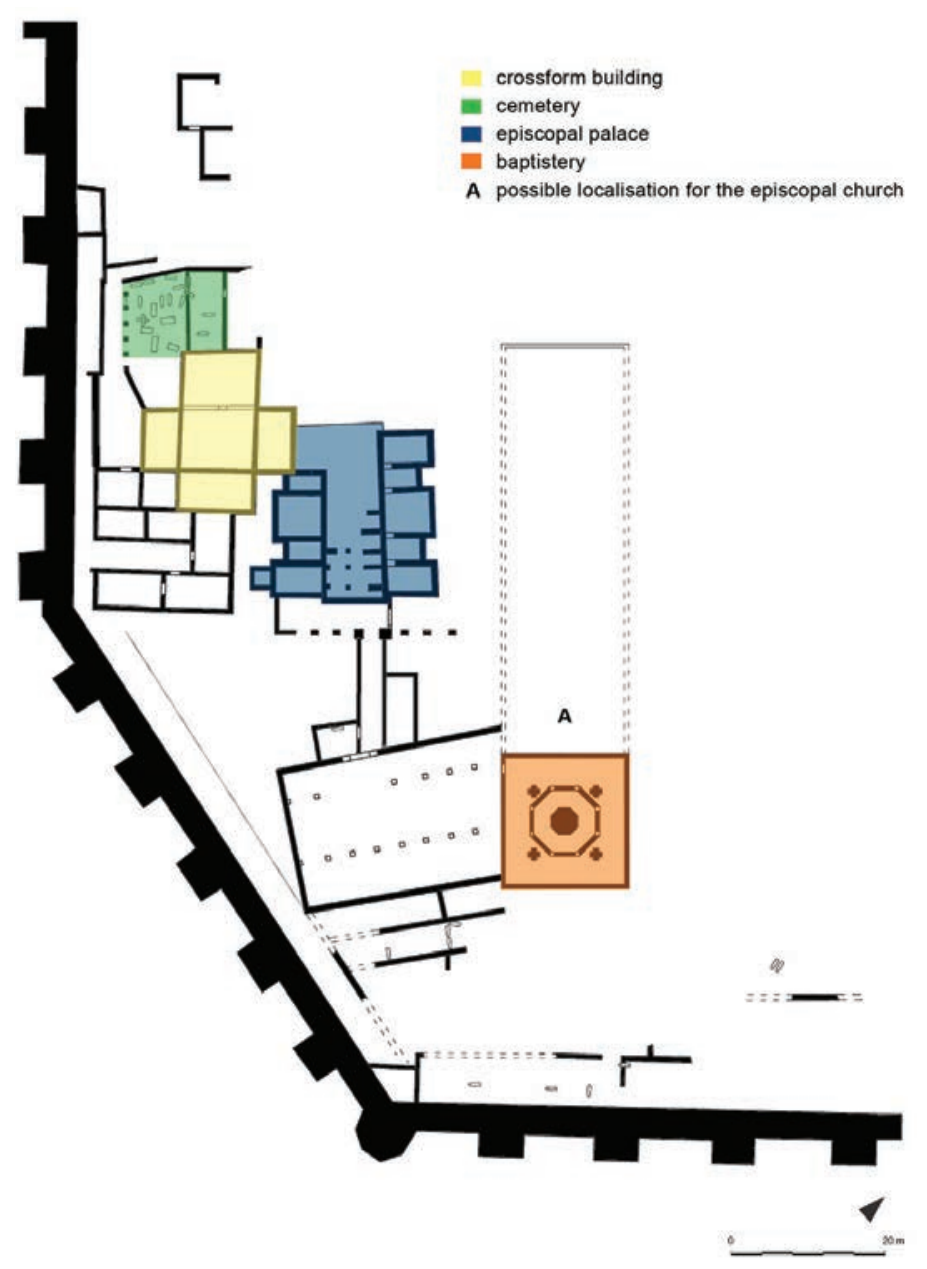

Fig. 2: The episcopal area of Barcino (Barcelona) during the mid 6th century.

at the moment we have no archaeological evidence, has been connected with a decorated epigraph bearing a cross with an alpha and omega, dated to $388^{26}$.

The rest of our information on early Hispanic churches come from the fifth century and later, and from written sources: according to an epistle sent by one Consentius to Saint Augustine, in Tarragona there was a secretarium linked to the cathedral in 420 (Augustine, Epistulae, $11^{*}, 9,1$ ). In this case also there is a chronological problem. Archaeological dating of the first structure of the cathedral, discovered in the upper party of the city, places it in the final years of the fifth century. However, in fact we know that there had been bishops there since the third century, and the monumental nature of the Christian sepulchres identified in the suburban necropolis of San Fructuosus attests a flourishing Christian community from the first half of the fourth century. The same document makes reference to a cathedral (episcopium) in Ilerda (Lleida) where the bishop Sagittius officiated. Hydatius mentions cathedrals and martyrial churches in Asturica and Bracara in the first half of the fifth century, and also a church (probably a cathedral) in Aquae Flaviae (Hydatius, Chronica, 86, 196). According to the same author,

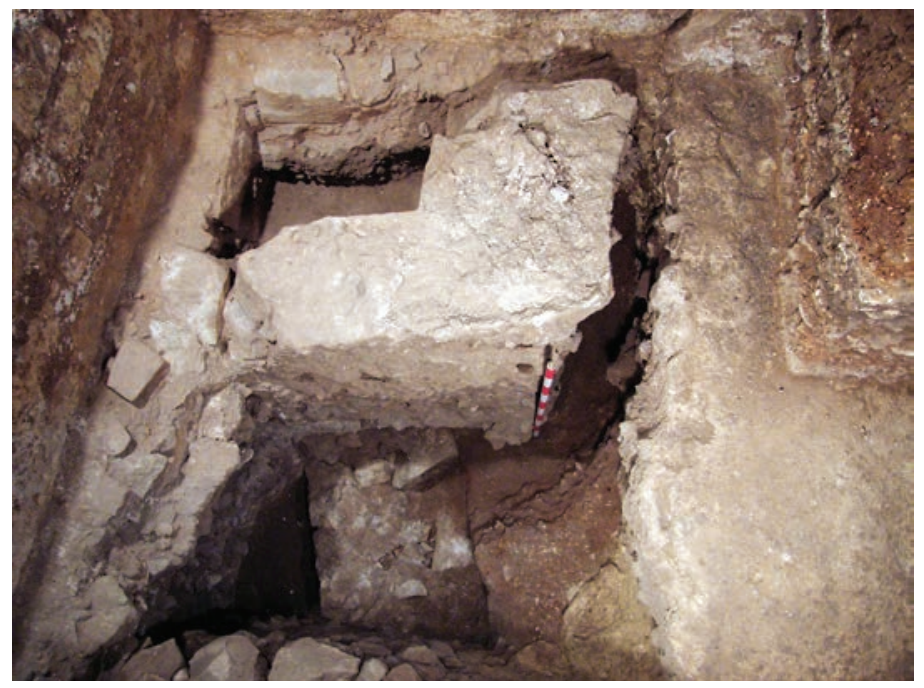

Fig. 3: Wall discovered during the excavations in the church of Sant just $i$ Pastor (Barcelona) interpreted as a baptistery and therefore episcopal complex (http://www.ara.cat/cultura/Lesglesia-Sants-Martirs-PastorVI_0_1318068346.html).

in Turiasso (Tarazona) in the mid fifth century the ecclesia served as a refuge for the bishop of Legio (León) and federated Visigoths, prior to the attack of the bacaudae (Hydatius, Chronica, 449). Reference is also made to the martyrial (and probably suburban) church of San Vicente de Hispalis (Hydatius, Chronica, 89).

In the fifth century, the shape of the baptismal font of the cathedral of Barcino was changed from square to octagonal, and a series of structures for liturgical and residential use were built close to the baptistery, consisting of a room attached to the baptistery, a bishop's residence and a balneum. In Egara also, the monumental phase of the churches has been dated to the second half of the fifth century, thus coinciding with its appointment as an episcopal see ${ }^{27}$.

However, more substantial archaeological evidence appears above all in the mid sixth century, when important activity relating to the construction and monumentalising of urban and suburban ecclesiastical architecture can be documented.

The baptistery in Barcino was renewed in the sixth century with a new floor in marble and pictorial decoration with inscriptions. At the same time, the episcopal complex was enriched with new monumental buildings, especially a bishop's palace and a church dated to between the years $530-595^{28}$, as we know from dating of mortars through ${ }^{14} \mathrm{C}$ archaeometric analysis (fig. 2). If we accept the ground plan reconstruction proposed by its investigators, we must note the cruciform plan of this church, which was also associated with an intramural cemetery. This practice (intra-urban cemeteries associated with churches), which has rarely been documented in other neighbouring regions such as Gaul and Italy, implies a remarkable transformation of Roman funerary traditions ${ }^{29}$ and in my opinion must be explained by significant cultural changes ${ }^{30}$.

${ }^{26}$ An inscription which is now lost. J.L. RODRÍGUEZ SADABA, P. MATEOS CRUZ, Catálogo de las inscripciones cristianas de Mérida, Mérida, 200o, n. 65, pp. 114-115 and 271 .

${ }^{27}$ G. GARCÍA, A. MORO GARCÍA, F. TUSET BERTAN, La seu episcopal d'Ėgara. Arqueologia d'un conjunt cristià del segle IV al IX, Tarragona, 2009.

${ }^{28}$ For Accelerator mass spectrometry (AMS) technique: J. BELTRÁN DE HEREDIA, Arquitectura y sistemas de construcción en Barcino durante la Antigüedad tardía. Materiales, tecnicas y morteros: un fosil director en el yacimiento de la plaza del Rey, "Quarhis", 5, 2009, pp. 142-169.

${ }_{29}$ A. CHAVARRÍA ARNAU, F. GIACOMELLO, Riflessioni sul rapporto tra sepolture e cattedrali nell'alto medioevo, "Hortus Artium Medievalium”, 20, 2014, pp. 209-220 and Sepolture e cattedrali in Italia settentrionale: il dato archeologico, "Rivista di Archeologia Cristiana”, 91, 2015, pp. 129-166.

$3^{\circ}$ But see also the doubts of Noel Duval concerning this building in La cathédrale paléochrétienne de Barcelone revisitée, "Bulletin Monumental", 1998, p. 156.4 , pp. 403-410. 


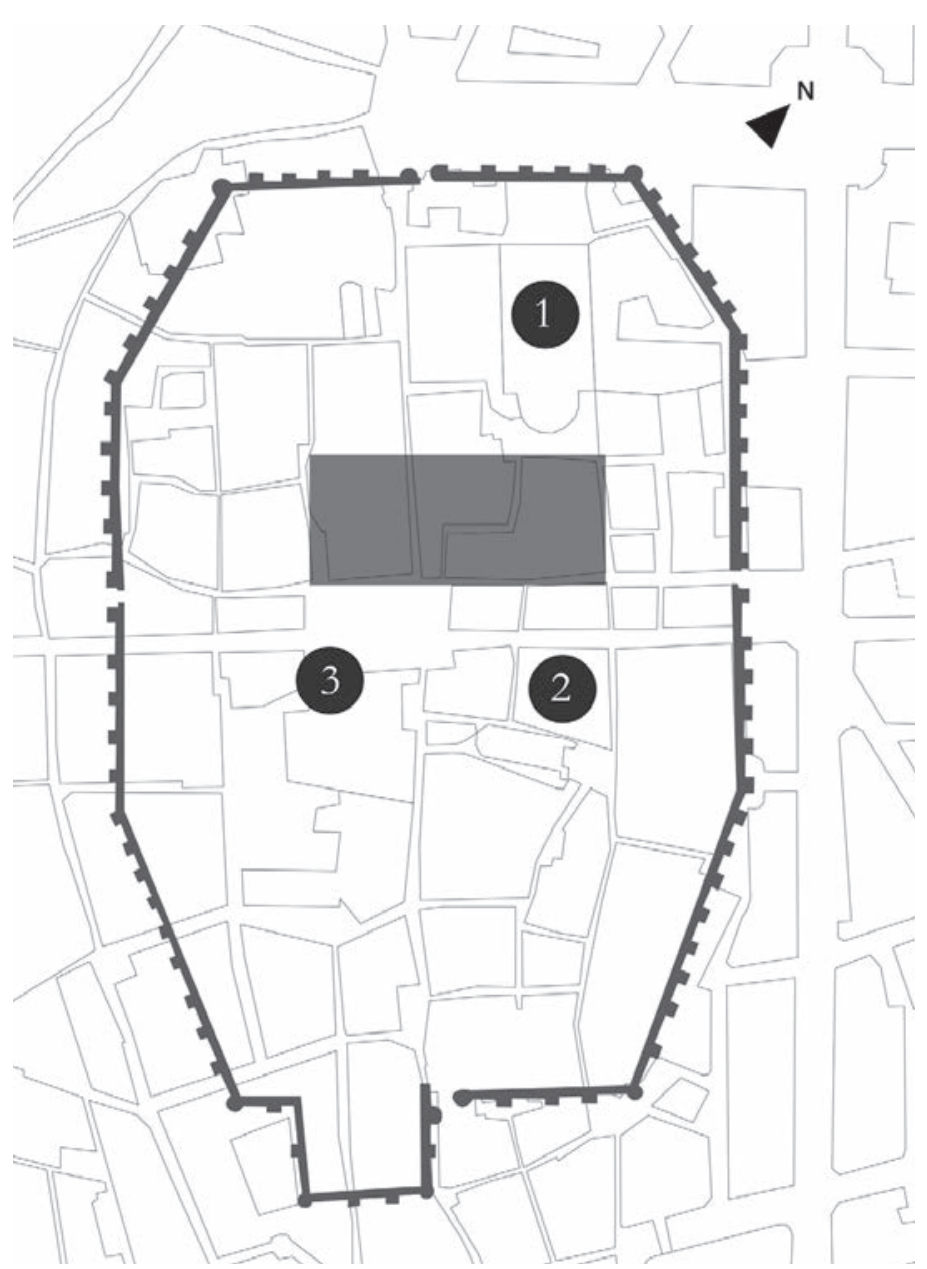

Fig. 4: Christian intramural topography of Barcino in the sixth century.
The recent excavations carried out beneath the church of Saints Justo and Pastor in Barcelona are of great interest, and appear to indicate the presence of another late antique building for worship in the city. This (together with the church of San Miguel, for example, and the suburban places of worship) allows us to form a more complete picture of the ecclesiastical topography of this urban centre (fig. 3). The proposal that the structure excavated there should be interpreted as a baptistery is less clear (fig. 4), and the theory that it was a Catholic baptistery before a hypothetical usurpation of the cathedral by the Gothic community is even more uncertain ${ }^{31}$.

Another ecclesiastical complex with a monumental phase that can be dated to the mid sixth century is that in Valentia where, in a central area of the city identified with the antique Roman forum, an interesting archaeological sequence has been investigated ${ }^{22}$ (fig. 5). Firstly, after the forum was abandoned in the mid fifth century, a cemetery with simple graves lacking grave-goods was established over the ruins. Later, and at a certain distance away, a monumental building was constructed, of which an enormous apse (12 $\mathrm{m}$. in diameter) has been preserved. This apse was flanked by two cruciform rooms which may have been added to the building later ${ }^{33}$. Both the apse and the annexes were built directly over the levels of Roman use and employing materials recovered from the ruins of the forum in the form of large stone blocks laid out regularly and making up a squared inner wall of very high quality. The foundations of the apse, also built from plundered material, extend for two metres which, together with the presence of buttresses, denotes a remarkable height for the building walls. This has been identified as the episcopal church of the city, with its two

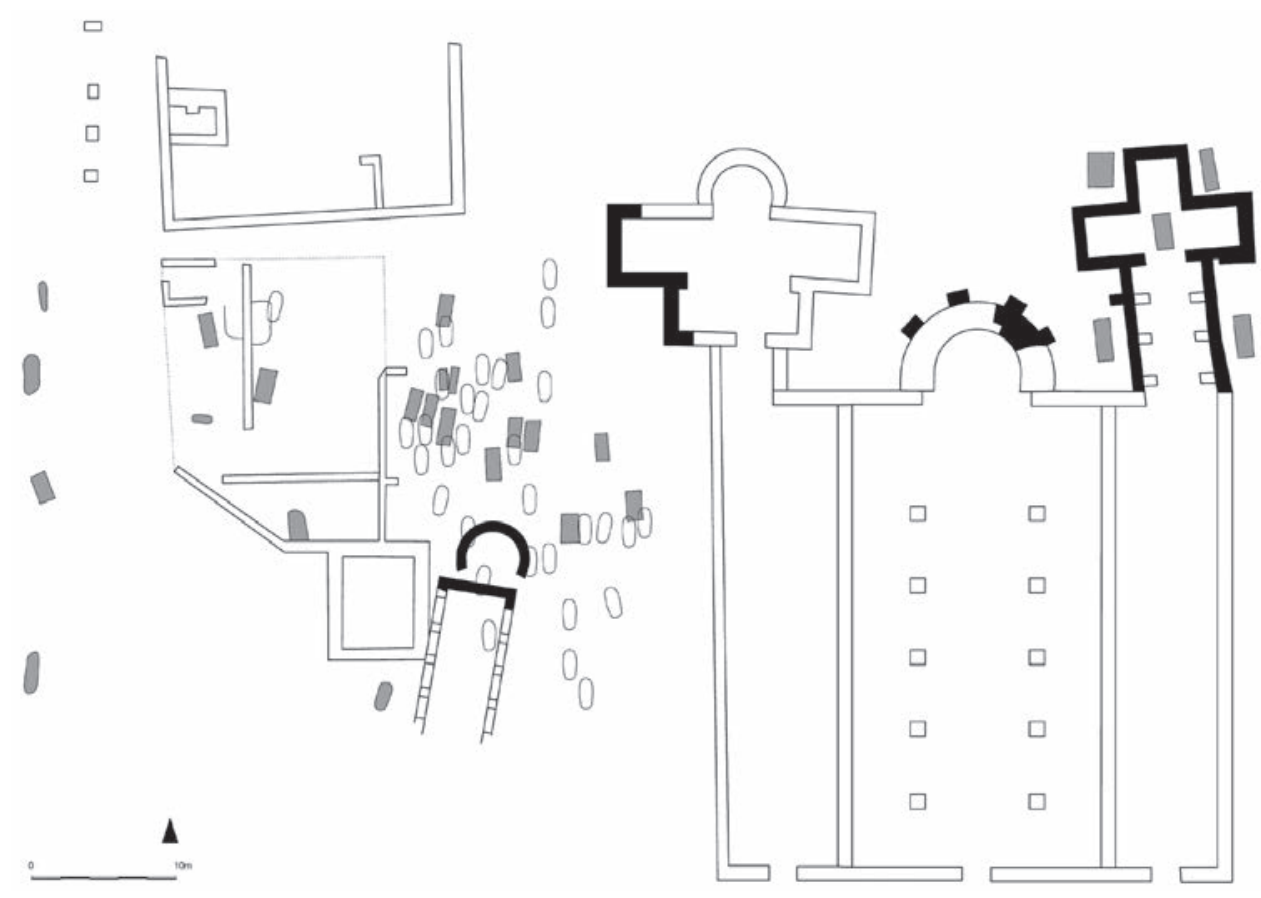

Fig. 5: Episcopal area of Valentia in the sixth century.

31. BELTRÁN DE HEREDIA, Barcelona, colonia de la Hispania romana y sede regia de la Hispania visigoda, in D. VAQUERIZO, J.A. GARRIGUET, A. LEÓN (eds.), Ciudad y territorio: transformaciones materiales e ideológicas entre la época clásica y el Altomedioevo, Córdoba, 2014, pp. 325-338.

${ }^{32}$ A. RIBERA, Los orígenes del Cristianismo en Valencia y su entorno, Valencia, 200o; A. RIBERA, La ciudad de Valencia durante el periodo visigodo, in E. OLMO (ed.), Recópolis y la ciudad en la época visigoda, 2008, pp. 302-321; A. RIBERA, M. ROSSELLÓ, Valentia en el siglo VII. De Suinthila a Teodomiro, in CABALLERO, L., P. MATEOS, Ma . A. UTRERO (eds.), El siglo VII frente al siglo VII. Arquitectura. Visigodos y Omeyas IV, Madrid, 2009 , pp. 185-203.

${ }^{33}$ The chronology of the construction of this church is placed - very generally - between the second half of the fifth century and the first half of the sixth (Ribera, La ciudad de Valencia, 305). In this latest publication, Ribera makes reference also to a building discovered "recently" beneath the baptistery 


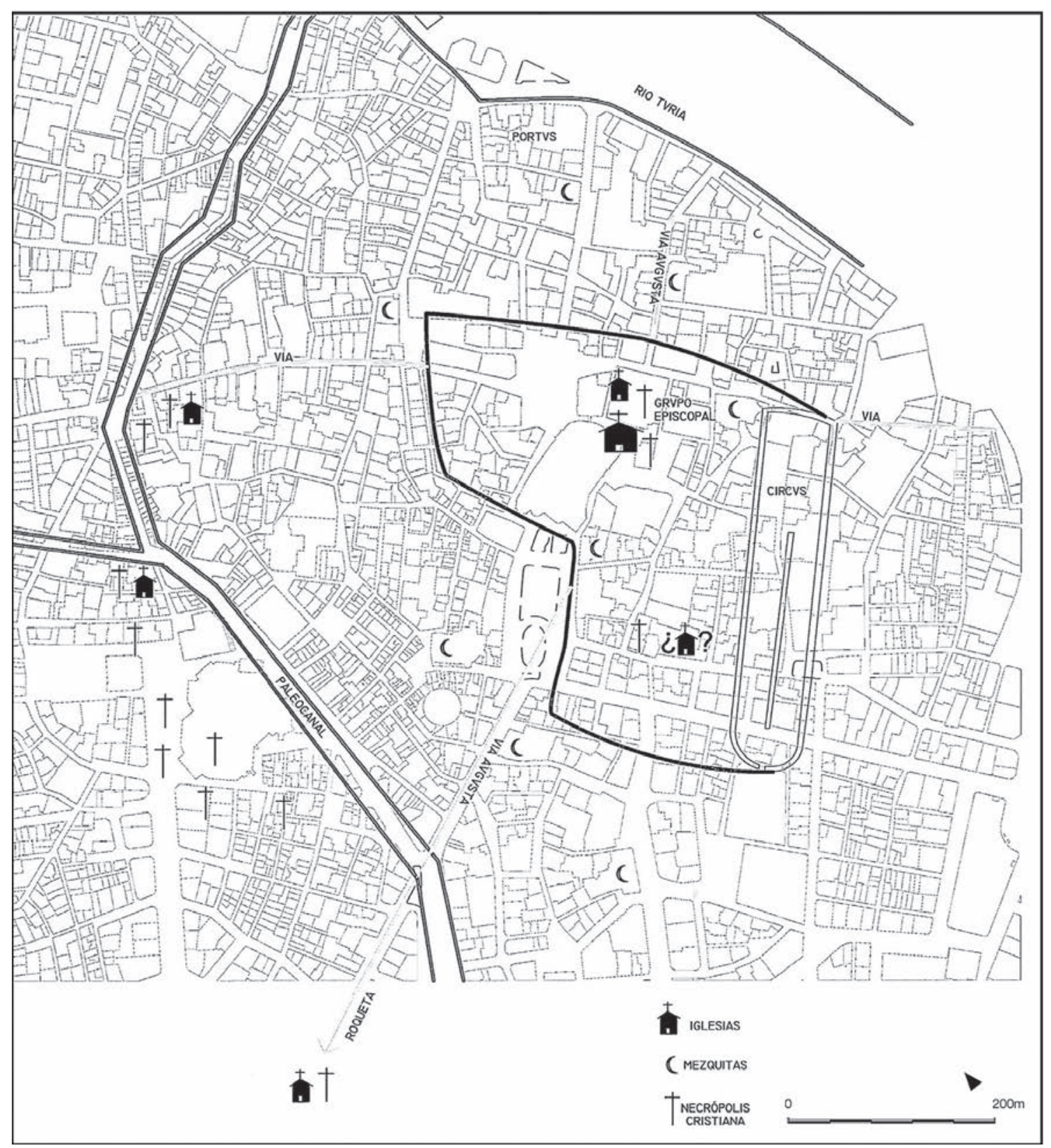

Fig. 6: Christian topography of Valentia in the sixth century.

annexes used respectively as a baptistery (northern annex) and martyrium-mausoleum (southern annex). In the centre of this latter building, a monumental tomb was set up, which can be dated (with ${ }^{14} \mathrm{C}$ dating) to the middle of the sixth century $^{34}$. Other monumental tombs were located outside and in the immediate vicinity. Finally, during a third phase, a new building was constructed within the area of the forum and near the episcopal church.

The sequence of this complex has been interpreted in connection with the passio of San Vicente: the location of the first necropolis is connected to a supposed prison of the saint, which gave rise to a first cemetery ad sanctos ${ }^{35}$. In the southern annex to the cathedral, according to its investigators, Bishop Justinian of Valencia, the initiator of all these works, may be interred and this cruciform building was built when the relics of the saint were brought from the suburbs to the centre of the city ${ }^{36}$. This suggestion is enormously evocative, but it needs to be borne in mind that the first cemetery dates from much later than the martyrdom (post middle of the fifth century), when Vicente had already become, according to Prudentius, a very well-known saint and so a cemetery ad sanctos would probably have been more monumental. Further, the identification of the prison is completely hypothetical as is the tomb of Justinian, bishop of the city at that time, who tradition indicates was more likely to have been buried in the suburban martyrial cemetery which is perhaps located in the area of "La Roqueta" (fig. $6)^{37}$. Bioarchaeological analyses of the skeletal material from

(from the second half of the sixth century) which may perhaps date construction of a first building for worship to the fifth century (Ribera, La ciudad de Valencia, 305-306).

${ }^{34}$ L. ALAPONT MARTIN, A. V. RIBERA I LACOMBA, Cementerios tardoantiguos de Valencia: arqueología y antropología, "Anales de Arqueología Cordobesa", 17, 2006, pp. 161-194; A. RIBERA, op. cit. (n. 32), pp. 314-317.

${ }_{3}$ C. MARÍN, A. RIBERA, Un edificio público Bajoimperial del Foro de Valentia, "Revista d'Arqueologia de Ponent", 9, 1999, pp. 277-29o.

${ }^{36}$ Traslatio dated to the sixth century (A. FABREGA I GRAU, Pasionario Hispánico (siglos VII -XI), Madrid-Barcelona, 1053-1955, pp. 195-196) and V. SAXER, La passion de Saint Vincent diacre dans la première moitié du V siècle. Essai de reconstitution, «Revue des études augustiniennes «, 35.2, 1989, pp. 275-297. 


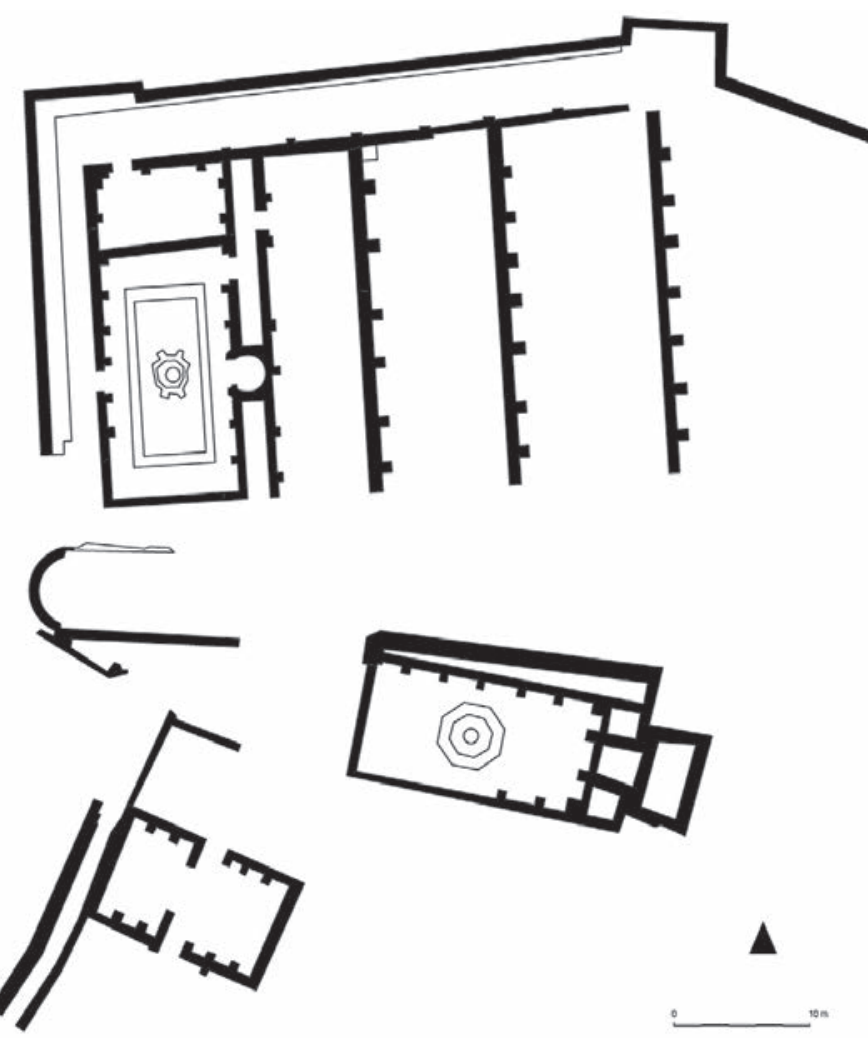

Fig. 7: Baptisteries discovered in Myrtilis (Portugal) both with monumental pools.

the funerary area linked to the cathedral is also interesting, as the skeletons display great differences with regard to the robustness of the individuals buried there ${ }^{38}$. This would accord with a change in the type of population who decided, against traditional Roman norms, to lay out a monumental and privileged cemetery right in the town centre.

A third urban ecclesiastical complex known from archaeological investigation is that in Mirtilis, where two monumental baptisteries have been identified - in this case, with certainty - 25 metres from each other ${ }^{39}$ (fig. 7). As in Barcino, the precise features of the churches with which the baptisteries were associated are not known, nor is their precise chronology. It is more than likely that both were active during the sixth century, as at least one of them was built at that time ${ }^{40}$, while the other belongs to the stages of initial Christianising of the city (fourth or fifth century) ${ }^{41}$.

In other cities, this monumentalising phase of urban churches (episcopal or otherwise) can be seen, particularly beginning with the decorative sculptures and liturgical furniture as at Emerita or Corduba.

\section{RURAL CHURCHES IN THE SIXTH CENTURY}

The multiplication churches and baptisteries during the sixth century was not only an urban phenomenon. On the contrary, there are many sites that have been identified in the countryside with the same features and chronology.

In previous publications I have addressed the problem of who built churches in the late antique countryside, and their relationship to land owners, and have cast doubt on an excessive tendency to attribute the construction of churches to rural landowners, an attribution which ignores the role of the bishop in the process of rural evangelisation in the fourth and fifth centuries ${ }^{42}$. To my knowledge, no rural churches are connected with habitations which were built during the fourth and fifth centuries, and so any connection to late Roman possessores appears to be very speculative.

In general, Hispanic rural churches from the sixth century are of remarkable size and had monumental baptismal installations. I believe it very likely that they were churches of the "parish" type, under the supervision of bishops who were responsible for maintenance of these buildings and managing the clergy who ran them. But in some cases (including the example of Torre de Palma among others see fig. 8.9 and 9.m) the monumentality of the baptismal font appears extraordinary for a rural complex. In the subsequent century, churches tended to become smaller, which indicates that they were not intended to bring in a very large congregation. The absence of baptisteries and, often, the presence of tombs, suggests that they should be interpreted as buildings for private worship and burial ${ }^{43}$.

Examples of rural churches built in the sixth century include those excavated in the Balearic Islands such as Son Bou, Son Peretò and Son Fadrinet (among others) ${ }^{44}$, Tarraconensis (El Bovalar, Villa Fortunatus), Baetica (El Germo, La Gerena, Vega del Mar) and Lusitania (such as Torre de Palma or Casa Herrera) (see figs. 8 and 9). In the latter two cases, at least, construction of the baptistery corresponds to a second stage of the complex and indicates a desire to monumentalise the space (where a baptistery had probably already existed earlier) and, likewise, the baptismal ritual. The size and depth of the fonts and, in a number of cases (e.g. Son Bou, cfr. fig. 8.10), their form, with clear roots in the pars orientalis of the Empire, is notable.

${ }_{37}$ On the problem of bishops burials see A. CHAVARRÍA ARNAU, Suburbia, iglesias y obispos. Sobre la errónea ubicación de algunos complejos episcopales en la Hispania tardoantigua, D. VAQUERIZO (ed.), Las areas suburbanas en la ciudad historica: topografía, usos y función, Córdoba, $2010, \mathrm{pp} .435-454$.

$3^{8}$ L. ALAPONT MARTÍN, La necrópolis de l'area episcopal de Valencia. Noves aportacions antropológiques, VI Reunió d’Arqueología Cristiana Hispánica (Valencia, 2003), 2005, pp. 245-250; L. ALAPONT MARTIN, A. V. RIBERA I LACOMBA, Cementerios tardoantiguos de Valencia: arqueología y antropología, "Anales de Arqueología Cordobesa", 17, 2006, pp. 161-194.

39 V. LOPES, A Antiguidade tardia em Mértola, balanço das novas descobertas arqueológicas, VII Encuentro de arqueología del suroeste peninsular, Huelva, 2015, pp. 823-839.

${ }^{40}$ Lopes dates it to the fifth century without bringing any explanatory data to justify this dating.

${ }^{41}$ Recently, a dual baptistery has also been proposed at the site of Idanha a Velha but in this case the first baptistery seems doubtful to me and the second one has not yet been associated with any church.

${ }^{42}$ A. CHAVARRÍA ARNAU, Aristocracias tardoantiguas y cristianización del territorio (siglos IV-V): ¿otro mito historiográfico?, "Rivista di Archeologia Cristiana", 82, 2006 [2007], pp. 201-230.

${ }^{43}$ A. CHAVARRÍA ARNAU, Churches and aristocracies in seventh century Spain: some thoughts on the debate on Visigothic churches, "Early Medieval Europe", 8. 2, 2010, pp. 160-174.

${ }^{44}$ C. MAS, M.A. CAU, Christians, Peasants and Shepherds: The Transformation of the Countryside in Late Antique Mallorca (Balearic Islands, Spain), "Antiquité Tardive", 21, 2013, pp. 27-42 and M. A. CAU, C. MAS , Tracing Settlement Patterns in Late Antique Mallorca (Balearic Islands): A Field Survey in the Eastern Territories, "Hortus Artium Medievalium", 19, 2013, pp. 247-265. 

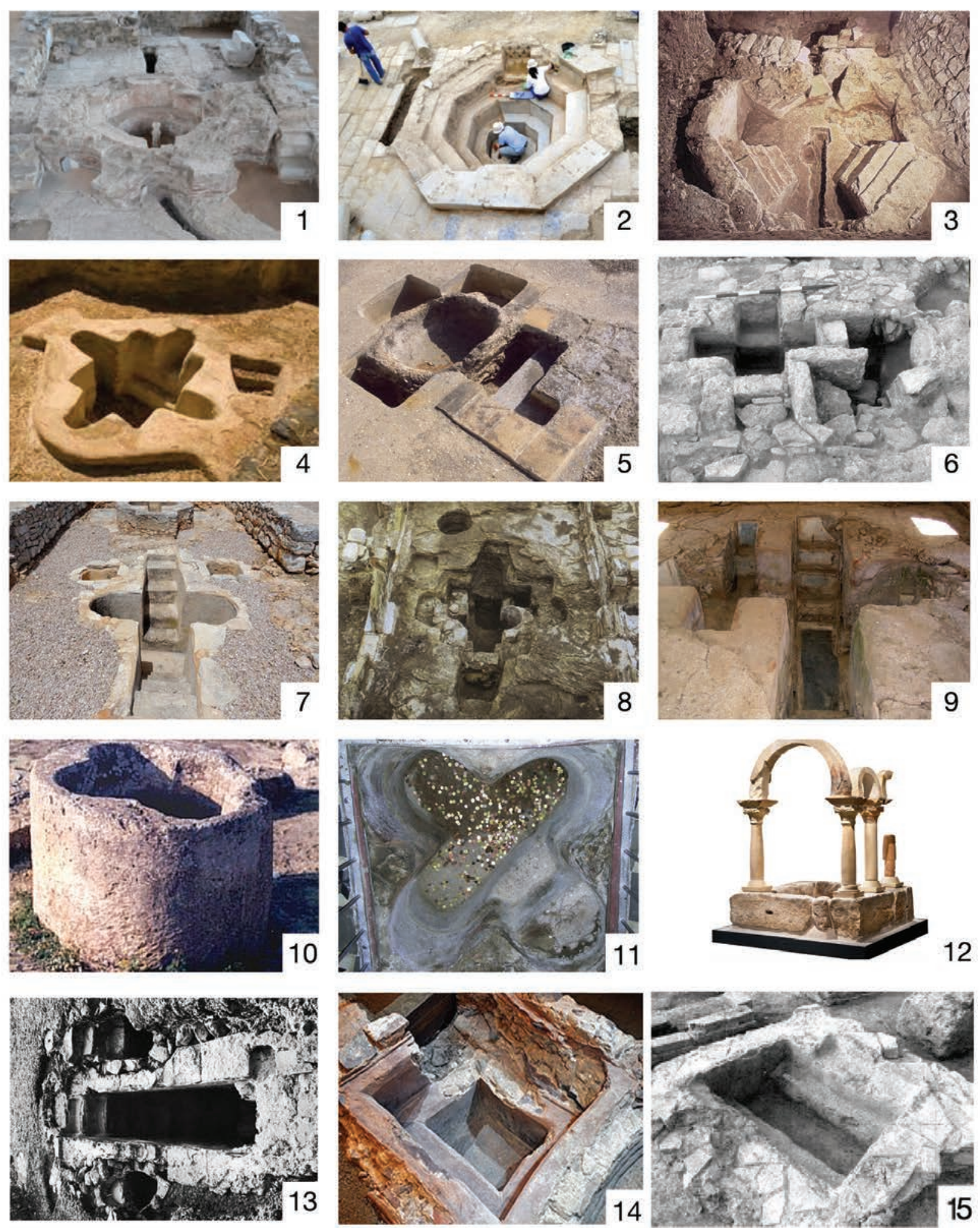

Fig. 8: Some monumental baptismal pools identified in late roman Hispania, many of them dated in the 6th century: 1-2. Mértola; 3. Barcelona; 4. San Pedro de Alcántara; 5. Lucerna; 6. Baños de la Reina; 7. Son Peretó; 8. El Tolmo de Minateda; 9. Torre de Palma; 10. Son Bou; 11. El Gijo; 12. El Bovalar; 13. Casa Herrera; 14. Terrassa; 15. Estepa.

\section{INTERPRETATION}

A large number of circumstances may have encouraged these developments in ecclesiastical architecture during the sixth century, which should be analysed case by case, city by city, based on the relevant political, economic and social context and the situation of bishops within this context. It is therefore essential to be able to date the various stages of construction precisely, in order to place them exactly in their proper historical setting.

It is sometimes tempting to attribute the monumentalisation of churches and their baptisteries to the period 530-580, a period of tension between the Catholic and Arian communities and their bishops, who lived side by side in Hispania. The construction of churches and baptisteries in the mid sixth century could thus be interpreted as a religious and political tool and as evidence of the conflicts between Arian and Catholic aristocracies. 


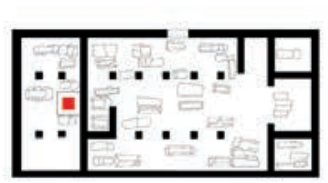

a

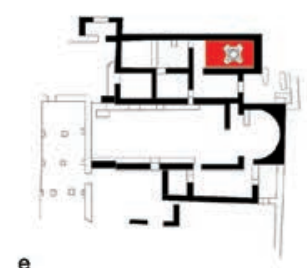

e

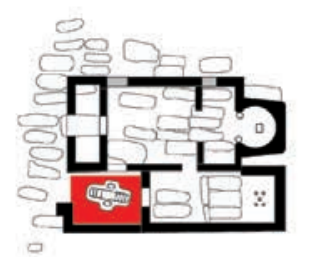

i

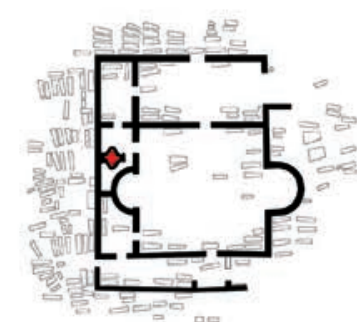

o

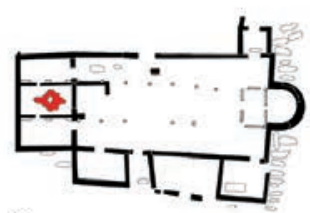

b

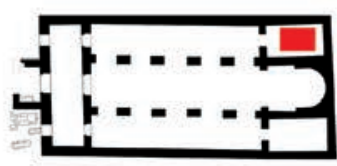

f
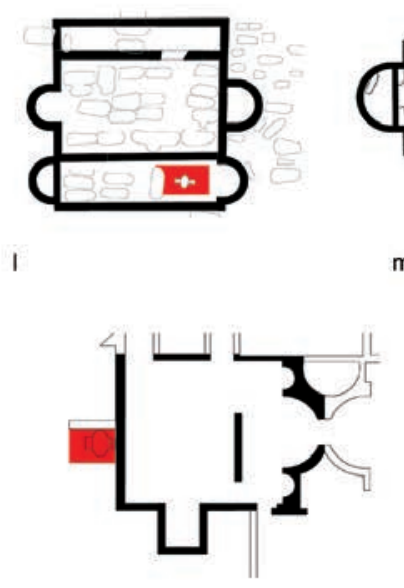

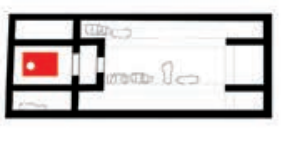

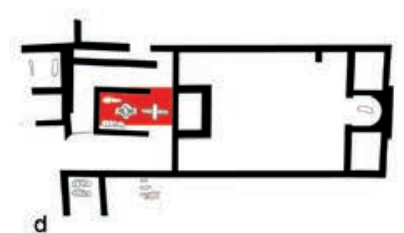

d

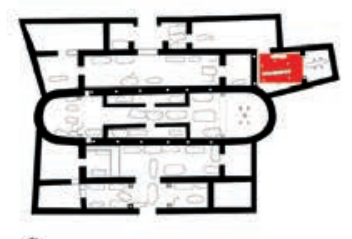

g
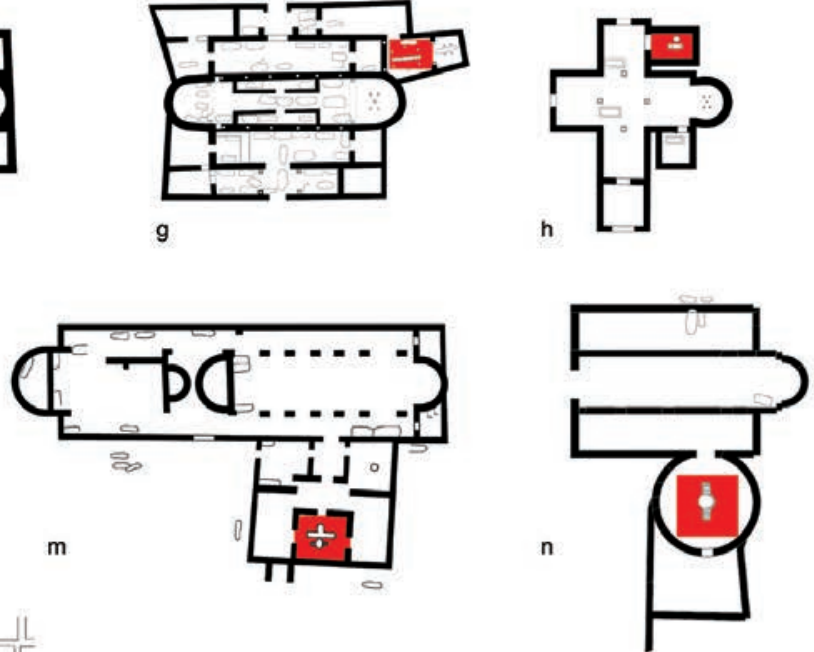

p

Fig. 9: Some monumental baptisteries identified in late roman Hispania: a. El Bovalar; b. El Tolmo de Minateda; c. Gerena; d. Son Peretó; e. Es cap des Port (Menorca); f. Son Bou; g. Casa Herrera; h. Valdecebadar; i. El Gatillo; l. El Germo; m. Torre de Palma (Monforte, Portugal); n. Algezares; o. San Pedro de Alcántara; p. El Saucedo (Talvera de la Reina)

The case of Emerita, which is well known through VSPE, is also very interesting. We may link the arrival in Mérida of Bishop Paul (around 530) to the beginning of Justinian's rule and of imperial expansion throughout the Mediterranean, as well as an expansion of Catholicism and orthodoxy in the context of the fight against heretical barbarians. This physician from the east was acclaimed as a bishop by local elites, who provided the economic means required to develop his religious control and, probably, opposition to Gothic authorities. It seems possible that Paul had been sent from the East to tackle the Arian Visigoths while based in one of the most important sees of the Peninsula. This is something that could also be suggested for the ecclesiastical missionary Martin, who came from imperial territories to Gallaecia at the same time as imperial troops landed in southern Spain, and who was later responsible for the conversion of the Arian Suebi45.

In Mérida, the escalation of tensions between Arians and Catholics was accompanied by a large number of building works undertaken during the reign of Liuvigild by Bishop Masona, to whom most banishments, confiscations and antiCatholic actions have been attributed, although building activity, and in all likelihood these conflicts, began prior to this with Bishop Fidel (560-571), the predecessor of Masona, who is credited with the reconstruction and decoration of the cathedral.

We know little from written sources, on the other hand, about the initiatives taken by Arian bishops, which is to be expected given that these activities must have been recorded by Arian sources that were destroyed after the conversion. The VSPE focus on the conflict between Catholics and Arians over the control of the shrine of Santa Eulalia and her relics, something that may have also happened in other cities for which no such detailed sources have been preserved. We know that in Corduba King Agila had opted for the opposite strategy years before (550), violating the sepulchre of the martyr Acisclus and turning the church into stables for his army, with dreadful results that led to the defeat of the king and the death of his son ${ }^{46}$.

Many argue that this type of religious polemic, based on very complex intellectual and theological debates, were unlikely to have been known (and, even less, understood) by most of the population of Hispania ${ }^{47}$. However, it is certain that the population was directly involved through the ritual

45 A. FERREIRO, Sueves and Martin of Braga: Historiographical and Future Research Projects, in E. KOLLER AND H. LAITENBERGER (eds.), SuevosSchwaben. Das Königreich der Sueben Auf der Iberischen Halbinsel (411-485), Tübingen, 1998, pp. 37-62 a much more positive view of this possibility than that published in A. FERREIRO, The Westward Journey of St. Martin of Braga, "Studia Monastica", 22, 1980, pp. 243-251.

${ }^{46}$ Isidoro, Historia Gothorum, 45 and Juan de Biclaro, Chronica, 20.

${ }^{47}$ Although Thompson notes that in Carthage Arians discussed the nature of the Trinity even in the baths (E. A. THOMPSON, The Conversion of the Visigoths to Catholicism, "Nottingham Medieval Studies", 4, p. 8, note 5, citing Victor Tommemsis III, 193 (of 498). 
of baptism, a key moment of entry into one or other of the confessions, and which therefore became a major issue for both groups and, additionally, an element that was essential for creating or strengthening the bond of loyalty between members of a social group and excluding those who did not belong to it. Baptism was one of the main causes of tension between Catholics and Arians and it is possible that its importance and symbolism for the practitioners of each of these confessions became more acute during the times of greatest conflict between them. A very significant account is given by Gregory of Tours of the violent (Arian) baptism to which Ingund, the wife of Hermenegild and daughter of the Frankish king Sigebert, was subjected, being dragged by the hair and thrown into the baptismal pool by her motherin-law, the evil queen Goiswintha, to convert her. Goiswintha was not only the mother in law of Ingund but also her maternal grandmother and the protagonist, according to Gregory of Tours, of the persecutions (magna persecutiones) inflicted upon Catholics during the reign of her husband King Liuvigild (Gregory Historiae, V, 38).

Liuvigild's replacement of Arian baptism by a laying on of hands suppressed the need to reiterate baptism, and was also the option preferred by Catholics for solemnising the conversion of Arians after 589. For this reason, the usual as- sumption that a multiplication of baptismal churches postdates the conversion period appears mistaken. Although it is certainly very difficult to distinguish archeologically whether a church was built before or after 589 (unless we have dedication inscriptions such as that of Gundiliuva, which specifically refers to the reign of Reccared ${ }^{48}$ ), I believe that it is the context prior to the Third Council of Toledo that explains the need to build baptismal churches, and not that of the subsequent period, when a triumphant Catholicism would not have been expressed in a reiteration of baptism since this had always been deemed an aberration by Catholics.

The question is of great interest and merits systematic investigation. Despite the scarcity of written sources and our complete lack of knowledge of the ecclesiastical structures of the Arian church, archaeology can offer essential new data regarding this particular historical period. If we add further evidence, such as the dating for Era in sixth century funerary inscriptions, considered to be a "specifically antiArian gesture" and an "expression of religious and regional identity" 49 , or an anti-Arian interpretation of many council canons, we can conclude that religious conflict and its consequences in politics, society and architecture were of fundamental importance in Hispania of the sixth century, and even subsequently.

\footnotetext{
$4^{8}$ Among many other studies on this particular inscription see: Y. DUVAL 1991, Nativola-les-Trois-Églises (Évêché d'Acci, 594-607) d'après Vives ICERV 303, "Mélanges de l'École Française de Rome. Antiquité", 103.2, pp. 807-820; A. M. CANTO, n. 121. Inscripción conmemorativa de tres iglesias, in Arte Islámico en Granada. Propuesta para un Museo de la Alhambra, Catálogo de la exposición, Granada, 1995, pp. 343-346; D. RICO CAMPS, Arquitectura y epigrafía en la Antigüedad Tardía. Testimonios hispanos, "Pyrenae", 40.1, 2009, pp. 7-53.

${ }_{49}$ M. A. HANDLEY, Tiempo e identidad: la datación por la Era en las inscripciones de la España Tardorromana y Visigoda, "Iberia”, 2, 1999, pp. 191-201, 197.
} 